\title{
THE FEATURES OF DEVELOPMENT OF AGRICULTURAL SECTOR OF ECONOMY OF UKRAINE IN THE CONDITIONS OF EURO INTEGRATION
}

\begin{abstract}
The article substantiates the peculiarities of the development of the agrarian sector of the economy in the context of integration into the EU, which confirms that the modern global society is undergoing transformational processes, in which Ukraine must take and takes part. It is determined that domestic agricultural science should promote more rational land use, create with the help of the latest information technologies the basis for increasing the range of agricultural products certified by the EU rules. The study of the positive experience of the EU countries regarding the use of raw materials for energy agricultural resources and the awareness of the objective need for finding alternative kinds of fuels and energy for Ukraine has given rise to the need to develop a bioenergy industry, which, in its turn will allow the introduction of an environmental ideology in the field of the production and consumption of bioenergy. The methodological approaches are determined, the theoretical conclusions are obtained which can be

(C) Ievgeniia Markova, Tetyana Shestakovska, 2017.

Markova levgeniia, The Doctor of Economics, Kherson Marine School of the Fisheries Industry, Ukraine, Kherson.

Shestakovska Tetyana, The Candidate of Economic Sciences, the Senior Lecturer Chernihiv National Technological University, Ukraine, Chernihiv.
\end{abstract}


used in the process of development of the strategy of agricultural development of Ukraine in the conditions of European choice while preserving its own identity.

\section{Key words:}

Agrarian sector, agroscience, agroecology, bioenergy, eurointegration, ecologically clean products, export, socioecological and economic policy.

JEL: O 52, Q 18.

Problem setting. The development of integration at the European level is a modern sign of progressive changes in the agrarian sector and a relatively new direction in the research of the national agrarian science. The European landmarks provide the agrarian sector with an appropriate vector of development and open up new opportunities for the revival of agriculture, create additional comparative advantages in the agro-food market in the conditions of globalization of the economy. In order to successfully solve the problems of European integration, the agrarian sector of Ukraine's economy has sufficient prerequisites: a rich natural resource and export potential, a significant human capital, a gradually growing investment attractiveness, a preserved pattern of rural life and centuries-old traditions of agriculture. Consequently, the level of readiness of the domestic agrarian sector of the economy to the conditions of European integration, as compared to the countries which joined the EU in the last wave of expansion, testifies that similar transformational changes in our country did not take place, which has caused the urgency of this article.

\section{The analysis of the recent research and publica-}

tions. The works by national economists-agrarians: V. Andriychuk, O. Borodina, V. Vlasova, Yu. Gubenya, S. Demyanenko, V. Zinovchuk, S. Kvasha, I. Kyrylenko, Yu. Lopatinsky, O. Mogylny, T. Ostashko, B. Paskhaver, P. Sabluk, O. Shubravskaya, G. Cherevko, V. Yurchyshin are devoted to research of con- 
crete directions of integration of the agrarian sector of economy in conditions of its reform, structural adjustment and the formation of priorities of European integration which allows to form a system of knowledge on the Eurointegration perspective of the domestic agrarian sector of economy.

The issues of the development of the agrarian sector of Ukraine's economy in the conditions of globalization and European integration are devoted to the works of such leading scientists as: V. Ya. Ambrosova, O. A. Bilovodskaya, O. D. Gudzinskaya, I.Yu. Gryshova, T. M. Gnatyeva, O.M. Halytsky, A.D Dibrova, S. M. Kvasha, T.M. Lozynskaya, O.B. Naumova, O. V.Mityay, S.S. StoyanovaKoval, B.O. Yazlyuk and others. Such contemporary scholars as O. Veklych, T. Kovalevskaya, O. Kolenov, O. Ostroverh and others have devoted their publications to the contemporary problems of environmental protection and determined the directions of the formation and implementation of the state ecological policy of Ukraine, in the context of European integration as well.

\section{The identification of the unexplored parts of the}

general problem. Despite the wide range of trends in the study of peculiarities of the development of the agrarian sector of Ukraine's economy in the context of globalization and European integration, the works of these scholars practically did not reflect the issue of development of theoretical and methodological approaches and organizational and practical principles of innovation activities of enterprises of Ukraine in order to adapt them to changing environment conditions. The issues regarding the formation of trends in the transformation of the state ecological policy in the conditions of European integration of Ukraine remain insufficiently researched.

Setting objectives. The determination of the directions of transformation of the state policy in the conditions of European integration in the context of ensuring the ecological safety of the agrarian sector of the national economy.

Presenting the essential material. In order to successfully solve the problems of European integration, the agrarian sector of Ukraine's economy has sufficient prerequisites: a rich natural resource and export potential, a significant human capital, a gradually growing investment attractiveness, a 
preserved pattern of rural life and centuries-old traditions of developing agriculture. In this context, the research and scientific understanding of the experience of creating the European agrarian model will contribute to the implementation of structural reforms in the field of agriculture and increase the level of competitiveness of agri-food products in the European and world markets (A. N. Kolenov, 2014, p. 108-113).

The evaluation of the main political, economic, social, environmental, scientific, technical, educational, professional factors of the model of the European integration, which analysis gives reasons to consider the integration process in the agricultural sector of the economy not as a one-time change in the quality of socio-economic environment, but as a complex and permanent process, directed to macroeconomic stabilization, creation of a favorable investment climate, development of competition, the improvement of labor quality, the diversification of rural economy of the price equilibrium of the agrarian market and stable funding (I. Yu. Gryshova, O. V. Mityaj, T. M. Gnatjeva, 2016, p. 25-35).

The purpose of the agrarian European integration is to combine the agrarian potentials of the member states (first of all, their agrarian markets and economic actors) with the subsequent modernization of agriculture and ensuring economic efficiency through mutual responsibility for the final results at all stages of agrarian cooperation and mutual interest of all participants of the integration process in a high level of food security of the countries-members of the association.

The folliwing basic principles of the process of European integration in the agrarian sector, are allocated: 1) the food security and sustainability of development; 2) efficiency and competitiveness; 3) the unity of purposeful and valuable rationality of the behavior of participants used by the countries-integrators in view of the existing natural-biological and socio-economic conditions of the functioning of the agricultural sector (The Law of Ukraine «On the main principles (strategy) of the state environmental policy of Ukraine for the period till 2020»; T. O. Zinchuk, 2007, Issue. 225, p. 595-603).

The modern principles of European integration in the agrarian sector of the economy represent an organic system and add certainty as for ensuring the sustainability of its development, allow to solve specific problems of the industry for a certain period of time, promote the creation of competitive environment, taking into account the interconnection of exogenous and endogenous factors.

Joining the EU gives the opportunity to use the communitarian mechanism for solving the problems of agricultural development, creates the necessary conditions for increasing the effect of integration measures and stimulates economic growth. But it would be wrong to assert that the benefits of integration are immediate and are obtained automatically by all countries without exception. Summarizing the main achievements and losses of the CEE countries as a result of the influence of the EUSAP on them, made it possible to highlight the most important 
steps towards European integration for Ukraine's agriculture. No matter how controversial was the experience of the countries of the last two waves of EU enlargement, the differences and problems in the development of the domestic agricultural sector are no more than in each separate country of this association.

At the forefront is the target setting for multifunctional agriculture, leaving it beyond the exclusive production of agricultural products.

Under the influence of changes in the period of full membership in the countries of the new wave of the EU, an appropriate social policy is formed. The traditional approach to social aspects consisted mainly in the formation of the labor market. The social sphere in general was presented only as a consumer of material and financial resources. With joining the EU, an important role in shaping the "protective social package» is given to agrarian policy implemented through social protection instruments.

The European perspective is an effective tool for reforming socioeconomic relations in the agricultural sector. It is desirable to implement the processes of adaptation of domestic agriculture to the conditions of the EU taking into account national components. In order to do this, it is important not to copy the achievements attained by the EU countries, but to find those priorities whose development can be guaranteed by synergetic and cumulative effects in the economic and social spheres of the agrarian economy.

Since the main criterion for providing public goods is the welfare of the population, in the field of state regulation it is advisable to focus on the priorities laid down in the latest reforms of the EUSAP. The relevant measures within the framework of this reform fully satisfy the interests of the population as a taxpayer, who, by investing in agriculture, expects to receive some public benefit from it.

The analysis of conducting business in the EU countries shows that agriculture is based mainly on family-type farms. Such a legal form of organization of agricultural enterprises corresponds to the specifics of agriculture as much as possible, providing in one person the functions of the land owner, employee and manager.

Within the framework of the current legislation in Ukraine there are various organizational and legal forms of agrarian business that are not adapted to the existing ones in the EU.

The further development of the market and entrepreneurial environment in the agrarian sector of the economy should be shaped in the context of taking into account both the benefits of large-scale enterprises and the increase of the competitiveness of medium-sized farms, which requires an appropriate institutional environment.

The agrarian policy of the state should be aimed at supporting the forms of management that allow the fullest use of existing potential both for ensuring food 


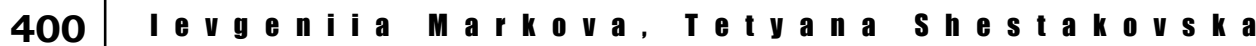

The features of development of agricultural sector of economy of Ukraine

in the conditions of euro integration

security, and for sustainable development of rural areas and supporting rural lifestyles (le.Yu. Markova, 2016, p. 70-86.).

The harmonization of the standards of the quality and safety of agricultural products with the requirements of the COP and the EU legislation is necessary. Harmonized standards for a domestic agricultural commodity producer are the only way to withstand the competition in the foreign market. The conducted studies indicate a low level of management system the quality of agro-food products and make it possible to reveal the main reasons for such a situation. The most important are the following: the existence of technical barriers; the uncertainty of approaches to strategic management of the system of managing the quality and the provision of appropriate methods for improving the safety of agri-food products.

The solution of the above mentioned problems is complicated due to the functioning of a complex, non-transparent, three-level standardization system in Ukraine. In order to have concrete bases for their implementation, integration and coordination of actions of all stakeholders involved in this process, strengthening of state supervision and control throughout the food chain; environmentalization of agrarian production are necessary. Ignoring the ecological factor in the agrarian reforms in Ukraine has led to a violation of the parity of economic, social and environmental interests that underlie the strategy of sustainable development. Compared to the EU, ecological agriculture has not been properly promoted in our country.

It is necessary to form the system of ecological agriculture in the medium term, which should meet the needs of the domestic market, taking into account the features of the European model of environmentalization of the industry. Since the organic production is not profitable and it is necessary to use high-value marketing measures for its development and support, we assume that in the shortterm prospects, the traditional importers of organic products will take the leading position in the market.

The development of overseas markets for environmentally friendly products is a real but long-term prospect for Ukraine. First of all, the system of public administration in this area should promote the development of the ecological direction in agriculture through the support of scientific development, harmonization of standards, development of technological and organizational regulations, as well as the state programs of ecologization with the provision of financial support. As a long-term perspective, taking into account the peculiarities of the European agrarian model, the strategy of ecologization of agrarian production is proposed; the formation and development of bioenergy markets.

With a positive example of the EU countries regarding the use of raw materials for energy agricultural resources and being aware of the objective need of searching for alternative kinds of fuels and energy for Ukraine, it is proposed to develop a bioenergy sector based on a rapeseed raw material base. This, in its 
turn, will allow the export of raw materials to be suspended and actually introduce an ecological ideology in the field of production and consumption of bioenergy.

The task of introducing an ecosystem approach to management activities and adapting the Ukrainian legislation in the field of environmental protection to the requirements of the EU directives is crucial in the year 2020.

The ecological legislation of Ukraine and the EU is significantly different, and their comparison points to certain shortcomings in the structure of the Ukrainian legislation, namely: the absence of such sections as: waste management, the control of the industrial pollution and risk management, chemicals and genetically modified organisms, noise from cars and the mechanisms that exist in the framework of the EU legislation (le. Yu. Markova, 2016, p. 70-86).Therefore, the main areas in which the approximation of the environmental legislation of Ukraine with the legislation enshrined in the environmental directives and legal acts of the EU is necessary: 1. Horizontal legislation (the assessment of the environmental impact, environmental information). 2. The quality of atmospheric air (the emissions from stationary and mobile sources, air quality standards, production control (ozone-depleting substances, the sale and use of hazardous chemicals) 3. Waste (waste processing and disposal, special waste (waste petroleum products, packaging materials, accumulators, (sludge, spent lubricating oils, batteries), hazardous waste (transportation, export, import)) 4 . The quality of water (city waste water (domestic, industrial), water policy, surface water (waber for swimming water and fishing anderground and drobking water) 5 . Wildlife (the natural environment of the existence of wild flora and fauna (birds, the protection of forests from atmospheric pollution and fires), the trade in species of wild plants and animals 6 . The control of industrial pollution, the control of risk from accidents (the integrated prevention of emissions, discharges and waste, the control of industrial risk, environmental safety, the system of ecological management and audit, the control of production (environmental labeling). 7. Chemicals and genetically modified organisms (chemical testing and the notification of chemicals (classification, packaging, marking), the use of genetically modified organisms, the control of production (asbestos, detergents), transportation, export, the import of hazardous substances 8. The level of noise (vehicles, machinery, mechanisms, appliances and construction equipment) 9. Nuclear safety and radiation protection (safety standards (health care of personnel and population), the transportation of radioactive substances and waste, the control of provisions. The priority actions to harmonize the environmental legislation of Ukraine with the requirements of the European Union include the following: the development and approval of new laws, in particular on the areas of emergency ecological situations, ecological insurance, fisheries, flora, ecological (natural and technological) safety; recreational zones, resorts, health-improvement zones and zones with special conditions of nature use, the Ecological Code, the laws on environmental information, environmental education. 
402 I e ve ni a Ma rk o va, I t y a na S hestak o v s a

The features of development of agricultural sector of economy of Ukraine

in the conditions of euro integration

In general, it should be noted that, according to experts, the adaptation of the environmental legislation of Ukraine to the standards of the European Union may cost 50-100 billion euros (I. Gryshova, W. Strielkowski, S. Kalyugina , 2017, p. 174-185).

Agricultural products, especially the part used for food production, should be not only qualitative, but also environmentally safe for life and health. The pollution of agricultural products, which makes them unsafe for consumers, is carried out as a result of pollution of the air, water and soils, uncontrolled use of pesticides and agrochemicals, contamination of agricultural land with mineral fertilizers, pollution of land and products, including textiles, heavy metals; contamination with dioxins and other poisonous substances; genetically modified foods.

The indicators of environmental safety of agricultural products are their quality, environmental safety and environmental cleanliness. The responsibility for the sphere of ensuring the ecological safety of food products according to the legistation of Ukraine is intrusted with the producer, therefore, it is proposed to make amendments to the contract. 7, part 6 artide article 20 of the Law of Ukraine "On the Safety and Quality of Food Products» concerning the consolidation of the complete generalized list of rights and obligations of producers: preventive, in the field of consumer rights protection, organizational and liquidation.

Agroecology, in addition to agricultural practices, has great potential for ensuring the growth of agricultural production along side with genetic engineering, biotechnology of production. Moreover, this growth will not be accompanied by harmful effects on the natural environment (The report on the implementation in 2011 of the Law of Ukraine «On the main principles (strategy) of the state environmental policy for the period up to 2020», 2012, p. 73; I. Gryshova, W. Strielkowski, S. Kalyugina, 2017, pp. 174-185).

In the «Doing Business 2016» rating, Ukraine ranks 83 out of 189 seats (Poland-25, Germany-15), rising 4 positions compared to 2015. The exports of Ukrainian agricultural products to the European Union increased by $\$ 68.2$ million in 2016 and amounted to $\$ 4.12$ billion. It is reported by the press service of the Ministry of Agrarian Policy and Food of Ukraine. It is noted that in 2015 the deliveries to the European Union amounted to $26,6 \%$ of all agrarian exports of the country. Mostly agricultural profucts were exported to the EU: Cereals (corn, wheat, barley) - 1279.5 million dollars; - Oil (sunflower, rapeseed, soya) 1185 million dollars; - Seeds of oilseeds (flaxseeds or rape seeds, soybeans, sunflower seeds) - \$587.5 million; - Residues and wastes of the food industry (cakes and other solid wastes obtained during the extraction of oil, soybean oil, waste from starch production, sugar, beet pulp, etc.) - \$439.2 million. 
Fig. 1

Scientific approaches to the formation of the objectives of the ecological economy

\begin{tabular}{|c|c|c|}
\hline & \multicolumn{2}{|c|}{ The objectives of the ecological economy } \\
\hline Economic & Ecological & Cultural \\
\hline$\downarrow$ & $\frac{1}{\eta}$ & $\downarrow$ \\
\hline $\begin{array}{l}\text { 1) to preserve the } \\
\text { population of the } \\
\text { region; } \\
\text { 2) to provide inhabitants } \\
\text { with high-quality food } \\
\text { products; } \\
\text { 3) to diversify the } \\
\text { economy; } \\
\text { 4) creation of new jobs; } \\
\text { 5) the consolidation of } \\
\text { the market }\end{array}$ & $\begin{array}{l}\text { 1) to preserve and improve soil } \\
\text { productivity; } \\
\text { 2) to create a closed system for the } \\
\text { exchange of materials; } \\
\text { 3) to reduce the pollution of open water } \\
\text { bodies and groundwater; } \\
\text { 4) to reduce emissions into the } \\
\text { atmosphere; } \\
\text { 5) to maintain the stability of the } \\
\text { ecosystem; } \\
\text { 6) to preserve the diversity of species of } \\
\text { the flora and fauna }\end{array}$ & $\begin{array}{l}\text { 1) to preserve the } \\
\text { agrarian cultural } \\
\text { traditions; } \\
\text { 2) to save the social } \\
\text { structure of the village; } \\
\text { 3) to preserve the } \\
\text { traditional rural } \\
\text { architecture; } \\
\text { 4) to preserve the } \\
\text { authentic agrarian } \\
\text { landscape }\end{array}$ \\
\hline
\end{tabular}

In 2016-2017, the marketing year compared with the previous period Ukraine increased sugar exports by 33 times - up to 344 thousand tons [8]. The main products of the Ukrainian export to European countries last year were (on cost indicators): cereals, oil, oilseeds, fruits and nuts. Also, among Ukrainian consumers, Ukrainian honey, meat, confectionery and juices were in great demand last year. Today we see an increase in the Ukrainian agrarian exports due to an increase in the supply of commodity groups such as sunflower oil by $\$ 505$ million, sunflower seeds by $\$ 36.1$ million, sugar by $\$ 16.5$ million. The most interesting for us is a significant increase in exports «Niche» fresh or processed products. Such as, for example, preserved tomatoes - by $\$ 14.3$ million, or twice, fresh and chilled vegetables -4 times, cucumbers -2.7 times, fresh fruits -2.5 times, margarine products -9 times, cocoa paste and cocoa butter, as well as ice cream, which in 2015 did not come to the EU at all. For Ukraine, this means a tendency towards diversification of the commodity structure of exports, which is a positive aspect. The imports of the European products to Ukraine also increased in 2016 and amounted to $\$ 1904.5$ million. The main products of import were food products such as sauces, coffee, tea and others $-\$ 233.6$ million, cocoa beans and chocolate $-\$ 113.7$ million, as well as cereals $-\$ 105.6$ million, etc.

The trade surplus of bilateral agricultural trade between Ukraine and the EU in 2016 amounted to over $\$ 2.3$ billion. The foreign trade turnover of agricul- 
404 I e ve ni a Ma rk o va, I t y a na s hestak o v s a

The features of development of agricultural sector of economy of Ukraine

in the conditions of euro integration

tural products between Ukraine and the EU countries amounted to $\$ 6182.9$ million in 2016. The major trade partners with the largest share in trade are: Spain $15,3 \%$, Poland $-14.3 \%$, the Netherlands $-14 \%$, Italy $-12.6 \%$, Germany $10.1 \%$, France $-8.4 \%$, Belgium $-3.2 \%$, Great Britain $-3 \%$, Portugal $-2.7 \%$, Romania $-2.2 \%$, Greece $-2 \%$, Hungary $-1.96 \%$ (The official site of the Ministry of Economic Development and Trade of Ukraine [Electronic resource]).

Gradually, go away references to the past, mainly aimed at economic results and the implementation of scientific advances, innovative technologies without taking into account the priority of the development of environmental and social factors. According to many scholars, all signs of an ecological crisis are observed in Ukraine, which is already considered as a crisis of the philosophy of being, the crisis of spirituality. The environmental degradation is the consequence of not only anthropogenic pressure on it, but also the impoverishment of the morality of the society, short-sightedness as for the future conflicts of an established standard of living. In this view, the main directions of the science of agroecology are at the forefront of overcoming the environmental problems in the agrarian sector (I. Yu. Gryshova, T. L. Shestakovska, 2017, p. 128-133; S. S. Stoyanova-Koval, 2016, p. 31-36).

Agroecology in the current difficult ecological and economic conditions should define a strategy for the development of agrarian production, aimed at preserving and reproducing, first of all, soil, water and biological resources, protecting the natural environment and providing people with high-quality food products in the necessary quantity.

By defining agroecology as a comprehensive and interdisciplinary science, ignoring its biogeochemical component is becoming increasingly irrelevant. The biocentric strategy of agriculture, as a condition for the formation of a balanced nature, utilization requires a comprehensive study of the living matter of the agrosphere.

For the evaluation and forecasting of agroecological processes it is important to calculate the coefficients of biogenic and physico-chemical migration of nutritive chemical elements - the coefficients of their biogenic accumulation, concentration, the coefficients of water mobility. The scientific value of the State monitoring of the lands can increase tenfold if we pass from the administrative and agro-soil zoning to the natural-functional, as well as increase the nonparametric part of the agro-chemical passport of the field and the number of investigated chemical elements-biofilms. The methodology of biogeochemical zoning makes it possible to estimate and predict the consequences of the ecological danger of most chemical elements for living organisms and endemic diseases of the population and is a significant criterion for shaping the territorial prospects for the development of food industry (L. M. Naumova, O. B. Naumov, V. V. Lebedeva, 2016, p. 38-42). 


\section{The conclusions and perspectives of further re-}

search in this direction. The domestic agrarian policy needs to be interpreted from the standpoint of the triple approach, which is widely used in the EU member states and takes into account the importance of not only economic, but also social and ecological components of the national economy, meets the requirements of the EU and confirms the overwhelming influence on the efficiency of agrarian production of a balanced system of measures and means of the state influence in close connection with rural development, agro-ecological requirements, full protection of the rural population and be continued to explore. The implementation of the proposed socio-economic and environmental priorities will provide an opportunity for an adequate transition of the agrarian sector of the economy to the European agrarian model of development and will promote the competitiveness of agriculture in the medium and long-term perspective of eurointegration.

\section{References}

1. Kolenov, A. N. (2014). International cooperation in the field of environmental protection as a mechanism for the formation of state environmental policy. The bulletin of the state and municipal government: cult-prosv. and educational. Journal. Orel. publisher A. Vorobjov,. No. 1., p. 108-113.

2. Gryshova, I. Yu. (2016). Competitiveness of agricultural enterprises as a key factor in sustainable development of agricultural sector. I. Yu. Gryshova, O. V. Mityay, T. M. Gnatyeva. Ukrainian Journal of Applied Economics. Volume 1., No. 2., p.p. 25-35. (In Ukreainian).

3. The Law of Ukraine "On the main principles (strategy) of the state environmental policy of Ukraine for the period till 2020" dated December 21, 2010, No. 2818-VI. [Electronic resource]. Retrieved from: http://zakon2.rada.gov.ua/ laws/show/2818-17/

4. Zinchuk, T. O. (2007). Food safety in the context of the European integration course of Ukraine: internal and external manifestations. Economics: the problems of theory and practice: Collection of scientific works. Dnipropetrovsk: DNU, Issue. 225, Volume. III., p. 595-603.

5. Markova, le.Yu. (2016). The strategic management of the production and economic activity of enterprises of the fishing industry: the problems of theory and practice. Monograph. Kherson: Ayalant, p. 70-86. 
406 I e ve ni a Markova, Tetya na shestak o v s a The features of development of agricultural sector of economy of Ukraine in the conditions of euro integration

6. The report on the implementation in 2011 of the Law of Ukraine «On the main principles (strategy) of the state environmental policy for the period up to 2020» (within the framework of implementation of the Agreement between the Government of Ukraine and the EU on the financing of the program «The support to the implementation of the Strategy of the National Environmental Policy of Ukraine»). K.: The Ministry of Ecology and Natural Resources of Ukraine, 2012. p. 73 (In Ukrainian).

7. Gryshova, I., Strielkowski, W., Kalyugina, S. (2017). Modern Technologies in Public Administration Management: A Comparison of Estonia, India and the United Kingdom. «Administration as a public Management». Vol. 28., p. 174185.

8. The official site of the Ministry of Economic Development and Trade of Ukraine. Retrived from: http: //www.me.gov.ua/Documents/Detail?lang=enUA\&id=5867bbb048-4922 -a3b4 ff2d1bb731a6 \& title = PokaznikiExportUkraine Za2016-Rik/

9. Gryshova, I. Yu., Shestakovska, T. L. (2017). The Asymmetry of the resource configuration and its destructive impact on the capitalization of agribusiness. The Scientific Papers of the Legislation Institute of the Verkhovna Rada of Ukraine. № 2. p. 128-133.

10. Stoyanova-Koval, S. S. (2016). The institutional transformation of the agrarian economy of Ukraine. Bulletin of Sumy National Agrarian University series «Economics and Management». No. 8 (69), p. 31-36.

11. Naumova, L. M., Naumov, O. B., Lebedeva, V. V. (2016). The concept of the development of agrarian and industrial production on the basis of crosssector integration. Sumy National Agrarian University Bulletin, series Economics and Management. No. 1 (67), p. 38-42. 